\title{
IMPLEMENTASI KEBIJAKAN ALOKASI DANA DESA (ADD) DI WILAYAH KECAMATAN RINGINREJO KABUPATEN KEDIRI
}

\author{
The Implementation Of Policy And Rural Fund Allocation (Add) In Ringinrejo County, Kediri \\ Regency, East Java
}

\author{
Pailan ${ }^{1}$ \\ ${ }^{1}$ Magister Ilmu Administrasi Universitas Kadiri
}

\begin{abstract}
Abstrak
Secara yuridis keberadaan desa diakui oleh undang-undang dan dinyatakan sebagai kesatuan masyarakat hukum yang memiliki batas-batas wilayah yang berwenang untuk mengatur dan mengurus urusan pemerintah, kepentingan masyarakat setempat berdasarkan prakarsa masyarakat, hak asal-usul dan/atau hak tradisional yang diakui dan dihormati dalam sistem Pemerintahan Negara Kesatuan Republik Indonesia (Undang-Undang Nomor 6 Tahun 2014 Tentang Peraturan Pelaksanaan Undang-Undang Nomor 6 Tahun 2014 tentang Desa). Secara garis besar pelaksanaan tersebut terangkum dalam hak otonomi daerah dan sebagai konsekuensi logis dari adanya kewenangan dan tuntutan dari pelaksanaan otonomi desa adalah tersedianya dana yang cukup. Alokai Dana Desa (ADD) adalah salah satu sumber pendapatan desa yang berasal dari dana perimbangan yang diterima kabupaten/kota. Praktik Alokasi Dana Desa sering menjadi permasalahan bagi desa sehingga pelaksanaanya kurang maksimal. Yang paling disoroti dalam penelitian ini adalah terkait dengan pertanggungjawaban ADD yang belum sesuai dengan ketentuan yang berlaku terutama mengenai kebijakan tentang Alokasi Dana Desa di Kecamatan Ringinrejo Kabupaten Kediri sesuai dengan Petunjuk Tenknis Alokasi Dana Desa Nomor 412.6/1843/418.63/2015 Perihal Petunjuk Teknis Alokasi Dana Desa Kabupaten Kediri Tahun 2015. Studi ini menggunakan metode penelitian kualitatif dengan pendekatan fenomenologi dan pendekatan survey guna memperoleh gambaran terperinci tentang fenomena dan fakta yang ditemukan. Hasil penelitian ini juga cukup mengejutkan dimana implementasi kebijakan Alokasi Dana Desa di desa-desa se-Kecamatan Ringinrejo Kabupaten Kediri masih belum maksimal sehingga perbengaruh terhadap proses pencairan dana desa, penyusunan APBdes tidak sepenuhnya menggambarkan kebutuhan yang diperlukan oleh desa, transparansi rencana penggunaan dan pertanggungjawaban APBdes rendah serta pertanggungjawaban keuangan desa belum sesuai standard dan rawan manipulasi.
\end{abstract}

Kata Kunci: Implementasi Kebijakan ADD; Alokasi Dana Desa; Kecamatan Ringinrejo Kediri

\section{Abstract}

The existence of the villages in Indonesia recognized by law and they are expressed as a unit of community with specific boundaries. Villages authorized to regulate and manage the affairs of the government, the interests of the local community based community initiatives, the right of the origin and/or customary rights recognized and respected in the administration system of the Republic of Indonesia (Undang-Undang Nomor 6 Tahun 2014 Tentang Peraturan Pelaksanaan Undang-Undang Nomor 6 Tahun 2014 tentang Desa). Based on their jurisprudence, villages in Indonesia have their autonomy rights to maintain their local governance and policy. As a logical consequence of their powers and demands of the implementation of a village is the availability of sufficient funds. The Rural Fund Allocation (ADD) is one of the villages' funds resource taken from the equalization funds received from the Regency holder Kediri. The practice of the allocation of rural fund allocation (ADD) mostly suffered to its procedure. The most prominent problem within this research is due to missing of the accountability and the lack of the right system that explicitly written in the Technical Direction from the related governance No. 412.6/1843/418.63/2015 about the technical details of the allocation of rural funds year of 2015. This study uses qualitative methodology with the phenomenology and survey approach to reveal and deep understanding of the facts and phenomena related to the research topic. We finally revealed several facts that prove the weaknesses relating to the policy on implementing rural funds (ADD) in villages of Ringinrejo Country, Kediri Regency that directly influences to the transfer process of the rural funds to the villages, 
weakness on ABPDes accountability and the lack of transparency. Therefore, the fund's accountability in the villages is the natural subject to the money manipulation.Keywords: Policy Implementation on Rural Funds Allocation, Rural Funds Allocation (ADD), Ringinrejo County.

Keywords: ADD policy implementation; rural fund allocation; kecamatan ringinrejo

A. PENDAHULUAN

Keberadaan Desa secara yuridis formal diakui dalam Undang-Undang Republik Indonesia Nomor 6 Tahun 2014 tentang Desa dan Peraturan Pemerintah Republik Indonesia Nomor 43 Tahun 2014 tentang Peraturan Pelaksanaan Undang-Undang Nomor 6 tahun 2014 tentang Desa. Berdasarkan ketentuan ini Desa diberi pengertian sebagai kesatuan masyarakat hukum yang memiliki batas-batas wilayah yang berwenang untuk mengatur dan mengurus urusan pemerintahan, kepentingan masyarakat setempat berdasarkan prakarsa masyarakat, hak asal-usul dan/atau hak tradisional yang diakui dan dihormati dalam sistem Pemerintahan Negara Kesatuan Republik Indonesia.

Agar dapat melaksanakan perannya dalam mengatur dan mengurus komunitasnya, desa berdasarkan Undang-Undang Nomor 6 Tahun 2014 pasal 18 disebutkan kewenangan desa meliputi kewenangan dibidang penyelenggaraan pemerintahan desa, pelaksanaan pembangunan desa, pembinaan kemasyarakatan desa, pemberdayaan masyarakat desa berdasarkan prakarsa masyarakat, hak asal usul dan adat istiadat desa.

Sebagai konsekuensi logis adanya kewenangan dan tuntutan dari pelaksanaan otonomi desa adalah tersedianya dana yang cukup. Beberapa faktor yang mempengaruhi kemampuan penyelenggaraan otonomi daerah, adalah kemampuan struktural organisasinya, kemampuan aparatur daerah, kemampuan mendorong partisipasi masyarakat dalam penyelenggaraan kegiatan pemerintahan, pembangunan, kemasyarakatan, serta kemampuan keuangan daerah (Rachim, Abd: 2015). Sadu Wasistiono (2006: 107) menyatakan bahwa pembiayaan atau keuangan merupakan faktor esensial dalam mendukung penyelenggaraan otonomi desa sebagaimana juga pada penyelenggaraan otonomi daerah. Untuk mengatur dan mengurus rumah-tangganya sendiri desa membutuhkan dana atau biaya yang memadai sebagai dukungan pelaksanaan dan kewenangan yang dimilikinya.

Implementasi otonomi bagi desa akan menjadi kekuatan bagi pemerintah desa untuk mengurus, mengatur, dan menyelenggarakan rumah-tangganya sendiri. Seiring dengan itu beban dan tanggung-jawab desa akan bertambah pula. Namun demikian penyelenggaraan pemerintahan tersebut tetap harus dipertanggungjawabkan terutama pertanggungjawaban dalam pengelolaan Anggaran Pendapatan dan Belanja Desa. Kendala umum yang dirasakan sebagaian besar desa terkait keterbatasan dalam hal keuangan desa. Seringkali Anggaran dan Pendapatan Desa (APBDes) tidak berimbang antara penerimaan dengan Pengeluaran. Kenyataan yang demikian disebabkan oleh empat faktor utama yaitu (1) desa memiliki APBDes yang kecil dan sumber pendapatan sangat tergantung pada bantuan yang sangat kecil pula, (2) kesejahteraan masyarakat desa rendah, (3) rendahnya dana operasional desa untuk menjalankan pelayanan, dan (4) bahwa banyak program pembangunan masuk ke desa tetapi masih dikelola oleh dinas.

Kabupaten Kediri merupakan salah satu daerah otonomi yang ada di jawa timur yang telah melaksanakan prinsip-prinsip otonomi daerah yang terus berusaha mengoptimalkan potensi desa demi terselenggaranya pemerintahan yang dinamis, kondusif dan bersih. Bukti nyata pemerintah kabupaten Kediri dalam membantu dan meningkatkan partisipasi pemerintah desa adalah dengan meningkatkan pemberian alokasi dana kepada desa guna mendukung penyelenggaraan, kewenangan dan urusan rumah tangga sendiri.

Fokus Penelitian

Yang menjadi fokus dalam penelitian ini mencakup beberapa hal sebagai berikut:

1. Pemindahbukuan dana Alokasi Dana Desa (ADD) dari rekening Kas Umum Daerah (RKUD) ke rekening Giro kas desa.

2. Perencanaan pelaksanaan penatausahaan maupun pelaporan dan pertanggungjawaban Alokasi Dana Desa.

3. Pencapaian tujuan pemberian Alokasi Dana Desa (ADD).

4. Faktor-faktor yang mendukung dan yang menghambat implementasi Alokasi Dana Desa (ADD).

Dalam penelitian ini peneliti berusaha mengungkap aspek-aspek tersebut berdasarkan sudut pandang teori kebijakan publik sesuai dari tema dari penelitian ini. Menurut William N. Dunn dalam bukunya Pengantar Analisis Kebijakan Publik (terjemahan Wibawa, Samodra dkk., 1994) implementasi kebijakan ditentukan oleh isi kebijakan dan konteks implementasinya. Isi kebijakan berkaitan dengan kepentingan yang 
dipengaruhi oleh kebijakan, jenis manfaat yang akan dihasilkan, derajat perubahan yang diinginkan, kedudukan pembuat kebijakan, siapa pelaksana program, dan sumber daya yang dikerahkan. Sementara itu konteks implementasi kebijakan berkaitan dengan kekuasaan, kepentingan dan strategi aktor yang terlibat, kareakteristik lembaga dan penguasaan dan kepatuhan serta daya tanggap pelaksana.

Subarsono (2005: 90) dalam bukunya mengutip pendapat George C Edward mengenai beberapa variabel yang mempengaruhi implementasi kebijakan publik yaitu (1) komunikasi, (2) sumberdaya, (3) disposisi (sikap), dan (4) struktur birokrasi. Keempat variabel tersebut saling berhubungan satu sama lain. Berikut adalah penjelasan mengenai keempat variabel tersebut:

1) Variabel komunikasi yaitu proses informasi mengenai kebijaksanaan dari pelaksanaan tingkat atas kepada aparat pelaksana di tingkat di bawahnya;

2) Variabel struktur birokrasi mencakup bagaimana struktur pemerintah, bagian tugas yang ada dan koordinasi yang dilakukan;

3) Variabel sumber daya; manusia, informasi dan sarana-prasarana yang tersedia dalam pelaksanaan kebijakan;

4) Variabel sikap merupakan variabel kecenderungan-kecenderungan atau disposisi aparat pelaksana.

Atas dasar hal yang telah diuraikan di atas dan dalam rangka untuk mengoptimalkan pemerintahan desa, pembinaan kemasyarakatan desa, pemberdayaan masyarakat desa dan pelaksanaan pembangunan desa maka pemerintah kabupaten Kediri mengeluarkan petunjuk teknis pelaksanaan Alokasi Dana Desa (ADD) tahun anggaran 2015 yang ditujukan kepada Camat dan Kepala Desa se-kabupaten Kediri. Petunjuk Teknis (JUKNIS) tersebut mengatur pelaksanaan pengelolaan keuangan yang berasal dari Alokasi Dana Desa (ADD) yang meliputi perencanaan, pelaksanaan, hakan, pelaporan dan pertanggungjawaban sesuai dengan ketentuan peraturan perundangundangan yang berlaku.

Sesuai peraturan Bupati Kediri Nomor 13 Tahun 2015 tentang Alokasi Dana Desa (ADD) dijelaskan bahwa arah penggunaan dana Alokasi Dana Desa (ADD) agar didasarkan pada skala prioritas tingkat desa yang merupakan hasil MUSRENBANGDES. Pelaksanaan Alokasi Dana Desa (ADD) wajib dilaporkan oleh tim pelaksana desa (TPK) secara berjenjang kepada tim fasilitasi tingkat kecamatan dan tim fasilitasi tingkat kabupaten. Untuk tingkat desa yaitu tim pelaksana kegiatan tingkat desa (TPK) wajib menyampaikan laporan bulanan penggunaan Alokasi Dana Desa (ADD) mencakup perkembangan pelaksanaan dan penyerapan dengan menggunakan format yang telah ditetapkan. Disamping itu pada setiap tahapan pencairan Alokasi Dana Desa (ADD) tim pelaksana desa wajib melaporkan kemajuan fisik yang merupakan visualisasi kegiatan fisik kepada tim fasilitasi kecamatan sedangkan pertanggungjawaban Alokasi Dana Desa (ADD) terintegrasi dengan pertanggungjawaban pelaksanaan APBDES.

Sistem pengelolaan dana desa yang dikelola oleh pemerintah desa termasuk di dalamnya mekanisme dan penghimpunan pertanggungjawaban merujuk pada UndangUndang No. 33 Tahun 2004 Tentang Perimbangan Keuangan Antara Pemerintah Pusat dan Pemerintah Daerah. Dalam aturan tersebut dijelaskan bahwa pendanaan pembangunan yang dilakukan pemerintah daerah termasuk didalamnya pemerintah desa menganut prinsip money follows function yang berarti bahwa pendanaan mengikuti fungsi pemerintah yang menjadi kewajiban dan tanggung jawab masingmasing tingkat pemerintahan. Dengan kondisi tersebut maka transfer dana menjadi penting untuk menjamin tercapainya standar pelayanan publik minimum (Simanjuntak, 2002).

Konsekuensi dari pernyataan tersebut adalah desentralisasi kewenangan harus disertai dengan desentralisasi fiskal. Realisasi dari desentralisasi fiskal di daerah mengakibatkan adanya alokasi dana desa (ADD), yang diberikan ke desa paling sedikit 10\% (sepuluh perseratus) dari perimbangan yang diterima kabupaten/kota dalam anggaran pendapatan dan belanja daerah setelah dikurangi dana alokasi khusus (DAK).

Dalam mendistribusikan ADD pemerintah Kabupaten Kediri menerapkan azas adil dan merata. Azas adil ditempuh dengan mengalokasikan bagaian ADD secara proporsional berdasarkan variabel kemiskinan, pendidikan dasar, kesehatan, keterjangkauan, jumlah penduduk, luas wilayah, potensi ekonomi, jumlah dusun dan jumlah aparat pemerintah desa. Sedangkan azas merata besaranya sama untuk setiap desa yang selanjutnya disebut dana desa minimum (ADDM). Menurut Kepala Badan Pemberdayaan Masyarakat dan Pemerintahan Desa (BPMPD) Kabupaten Kediri, Satirin menjelaskan besar ADD yang dianggarkan dalam APBD Kabupaten Kediri Tahun 2015 sebesar Rp. 124 milyar. Besaran anggaran tersebut empat kali lipat dari anggaran sebelumnya sebesar Rp. 31 milyar. Besar anggaran dari ADD yang diterima masing-masing desa tahun 2015 berkisar Rp. 290 
juta hingga Rp. 670 juta. Menurutnya dana yang ditransfer ke desa dikonsentrasikan untuk kebutuhan masyarakat terutama swasembada pangan yang penganggarannya di tingkat desa ada pada Rencana Anggaran Biaya (RAB). Realisasi besaran anggaran yang diterima di Kecamatan Ringinrejo minimal Rp.339.998.000 (desa Nambaan), sedangkan yang tertinggi diterima desa Deyeng sebesar Rp.433.514.000. Kecamatan Ringinrejo merupakan kecamatan baru (kecamatan pengembangan) di kabupaten Kediri sehingga sangat menarik untuk dilakukan penelitian tentang implementasi kebijakan Alokasi Dana Desa (ADD). Selain itu, penelitian di desa-desa Kecamatan Ringinrejo dilakukan dengan pertimbangan bahwa peneliti selaku anggota Badan Permusyawaratan Desa (BPD) di salah satu desa di kecamatan Ringinrejo ingin mengetahui sejauh mana implementasi kebijakan alokasi dana desa di desa-desa kecamatan Ringinrejo.

Pada kenyataanya pengelolaan ADD di desa-desa kecamatan Ringinrejo belum sepenuhnya berhasil karena beberapa faktor. Yang paling disoroti adalah terkait dengan pertanggungjawaban ADD yang belum sesuai dengan ketentuan yang berlaku.

Berdasarkan laporan hasil pemeriksaan Inspektorat Kabupaten Kediri atas pengelolaan keuangan desa terhadap 6 (enam) desa di wilayah kecamatan Ringinrejo, khususnya untuk pengelolaan ADD belum sepenuhnya sesuai dengan ketentuan yang ditetapkan.

Permasalahan dalam pelaksanaan alokasi dana desa dijumpai juga pada kemampuan pengelola alokasi dana desa baik dari unsur pemerintah desa maupun lembaga kemasyarakatan di desa dalam perencanaan, pelaksanaan dan pengendalian kegiatan yang belum transparan. Diantaranya adalah kurangnya komunikasi antara unsur pemerintahan desa dengan lembaga-lembaga kemasyarakatan maupun tokoh-tokoh masyarakat maupun komponen masyarakat yang mempunyai potensi dalam MUSRENBANGDES penggunaan alokasi dana desa sebagaimana tidak disebutkan dalam surat Bupati Nomor 412.6/1843/418.63/2015 tentang Petunjuk Teknis Pelaksanaan Alokasi Dana Desa (ADD) Tahun 2015.

Dalam pelaksanaan kebijakan alokasi dana desa, Kepala Desa belum begitu melibatkan lembaga-lembaga kemasyarakatan desa. Kegiatan dalam bantuan alokasi dana desa pemberdayaan masyarakat lebih banyak ditangani oleh Kepala Des aatau Tim Pelaksana yang ditunjuk oleh Kepala Desa. Disamping itu, dalam penyelesaian administrasi kegiatan juga sering terlambat, sehingga sering terjadi keterlambatan dalam pencairan dana Alokasi Dana Desa (ADD) Tahap II.

Tentunya hal ini tidak sejalan dengan Peraturan Daerah Kabupaten Kediri Nomor 6 Tahun 2006 Tentang Sumber Pendapatan Desa dalam Prinsip-prinsip Pengelolaan Alokasi Dana Desa (ADD) bahwa seluruh kegiatan yang didanai oleh Dana Alokasi Dana Desa (ADD) harus direncanakan, dilaksanakan ditatausahakan, dilaporkan dan dipertanggungjawabkan secara akuntabel dan transparan sesuai ketentuan undang-undang yang berlaku.

\section{B. KERANGKA TEORI}

\subsubsection{Desa dan Pemerintahan Desa}

Pengertian desa menurut Permendagri nomor 113 tahun 2014 : “desa dan desa adat atau yang disebut dengan nama lain, selanjutnya disebut desa, adalah kesatuan masyarakat hukum yang memiliki batas wilayah yang berwenang untuk mengatur dan mengurus urusan pemerintahan, hak asal usul, dan/atau hak tradisional yang diakui dan dihormati dalam sistem pemerintahan Negara Kesatuan Republik Indonesia". Sementara pemerintahan desa menurut Permendagri nomor 113 tahun 2014 : "penyelenggaraan urusan pemerintahan dan kepentingan masyarakat setempat dalam sistem pemerintahan Negara Kesatuan Republik Indonesia. Pemerintahan desa diselengggarakan oleh pemerintah desa, dimana pemerintah desa berdasarkan Permendagri nomor 111 tahun 2014 adalah kepala desa atau yang disebut dengan nama lain dibantu perangkat desa sebagai unsur penyelanggaran pemerintahan desa.

\subsubsection{Undang-Undang Desa}

Undang-undang nomor 6 tahun 2014 tentang desa (selanjutnya disebut undang-undang desa) disahkan oleh Presiden Susilo Bambang Yudhoyono pada tanggal 15 Januari 2014. Pengesahan undang-undang tersebut menggantikan Peraturan Pemerintah (PP) nomor 72 tahun 2005 tentang desa.

\subsubsection{Akuntabilitas}

\subsubsection{Pengertian Akuntabilitas}

Pengertian akuntabilitas publik menurut (Mahmudi, 2010: 23) adalah "kewajiban pemerintah (agent) untuk mengelola sumber daya, melaporkan, dan mengungkapkan segala aktivitas dan kegiatan yang berkaitan dengan penggunaan sumber daya publik kepada pemberi mandat (principal)".

\subsubsection{Jenis-Jenis Akuntabilitas}

1. Akuntabilitas hukum dan kejujuran (accuntability for probity and legality)

2. Akuntabilitas manajerial

3. Akuntabilitas program 
4. Akuntabilitas kebijakan

5. Akuntabilitas keuangan atau finansial

2.1.4 Akuntansi Desa dan Pengelolaan Keuangan Desa

Akuntansi desa menurut (Sujarweni, 2015: 17) adalah : "pencatatan dari proses transaksi yang terjadi di desa, dibuktikan dengan nota-nota kemudian dilakukan pencatatan dan pelaporan keuangan, sehingga akan menghasilkan informasi dalam bentuk laporan keuangan yang digunakan pihak-pihak yang berkepentingan dengan desa". Sedangkan pengelolahan keuangan desa berdasarkan Permendagri nomor 113 tahun 2014 meliputi perencanaan, pelaksanaan, penatausahaan, pelaporan, pertanggungjawaban, pembinaan dan pengawasan keuangan desa. Proses pengelolaan keuangan desa berjalan selama 1 (satu) tahun anggaran mulai tanggal 1 Januari sampai dengan tanggal 31 Desember.

\section{METODE PENELITIAN}

Jenis penelitian ini merupakan penelitian kualitatif dengan pendekatan deskriptif komparatif. Menurut (Sarosa, 2012: 7) penelitian kualitatif adalah "penelitian yang mencoba memahami fenomena dalam seting dan konteks naturalnya bukan di dalam laboraturium dan peneliti tidak berusaha untuk memanipulasi fenomena yang diamati". Pada penelitian ini peneliti mendiskripsikan pengelolaan keuangan desa di Desa Ringinrejo yang meliputi: perencanaan, pelaksanaan, penatausahaan, pelaporan, pertanggugjawaban, pembinaan dan pengawasa pengelolaan keuangan desa serta mengkomparatifkan kesesuaianya dengan undang-undang nomor 6 tahun 2014 tentang desa.

Pada penelitian ini teknik pengumpulan data menggunakan teknik:

1. Wawancara, merupakan salah satu alat yang paling banyak digunakan untuk mengumpulkan data penelitian kualitatif karena memungkinkan peneliti mengumpulkan data yang beragam dari responden.

2. Dokumentasi, teknik pengumpulan data berupa dokumen-dokumen atau arsip-arsip yang dapat memberikan informasi terkait data penelitian.

3. Studi kepustakaan, dilakukan untuk mengumpulkan data yang bersumber dari literatur-literatur yang berhubungan dengan topik penelitian.

Penelitian ini mengunakan prosedur analisis data kualitatif model Miles dan Huberman (Emzir: 2012. 129). Terdapat tiga macam kegiatan analisis data kualitatif, yaitu:

1. Reduksi data, data yang diperoleh dari lokasi penelitian (data lapangan) dituangkan dalam uraian atau laporan yang lengkap dan terperinci.

2. Penyajian data, bertujuan memudahkan peneliti untuk melihat gambaran secara keseluruhan atau bagian-bagian tertentu dari penelitian.

3. Penarikan kesimpulan atau verifkasi data, dalam penelitian kualitatif dilakukan secara terusmenerus selama penelitian berlangsung. Sejak awal memasuki lapangan dan selama proses pengumpulan data, peneliti berusaha menganalisis dan mencari makna dari data yang dikumpulkan dengan mencari pola, tema, hubungan persamaan, hal-hal yang sering timbul, dan yang dituangkan dalam kesimpulan.

\section{PEMBAHASAN}

1. Pemindahbukuan dana Alokasi Dana Desa (ADD) dari RKUD ke rekening kas giro desa sudah sesuai dengan aturan dalam JUKNIS Bupati Kediri Nomor: 412.6/1843/418.63/2015. Akan tetapi masih ditemui kendala dalam proses pencairan oleh desa ataupun pendistribusian dari kepala desa ke bendahara.

2. Implementasi Kebijakan Alokasi Dana Desa (ADD) di Kecamatan Ringinrejo Kabupaten Kediri berjalan cukup lancar. Hal ini dapat terlihat dari tahap persiapan berupa penyusunan Daftar Usulan Rencana kegiatan (DURK), penyelesaian setiap kegiatan sampai dengan tahap penyusunan pertanggungjawaban.

Dalam penyusunan APBdes satuan harga baku barang dan jasa belum ada. Penyusunan APBdes tidak sepenuhnya menggambarkan kebutuhan yang diperlukan oleh desa. Transparansi rencana penggunaan dan pertanggungjawaban APBdes rendah serta pertanggungjawaban keuangan desa belum sesuai standard dan rawan manipulasi.

3. Pencapaian tujuan pemberian Alokasi Dana Desa (ADD) belum optimal. Hal ini dapat dilihat dari pencapaian tujuan Alokasi Dana Desa (ADD), yaitu meningkatnya penyelenggaraan pemeritahan, pembangunan dan kemasyarakatan, meningkatnya kemampuan lembaga kemasyarakatan di desa dalam perencanaan, pelaksanaan dan pengendalian pembangunan serta mendorong peningkatan partisipasi swadaya gotong-royong masyarakat.

Pertama peningkatan penyelenggaraan pemerintahan, pembangunan dan kemasyarakatan, pencapaian tujuan ini telah terlaksana secara optimal. Pencapaian tujuan ini menjadi optimal dikarenakan desa-desa di 
wilayah Kecamatan Ringinrejo adalah desa yang dikategorikan miskin sehingga sangat membutuhkan bantuan dana guna peningkatan penyelenggaraan pemerintahan, pembangunan dan kemasyarakatan. Berdasarkan data yang penulis temukan di wilayah Kecamatan Ringinrejo, yaitu Pendapatan asli desa memberikan kontribusi pada pendapatan desa sebesarRp. 4.335.684.900,- atau 21,20 \%. Sedangkan Alokasi Dana Desa di wilayah Kecamatan Ringinrejo Kabupaten Kediri memberikan kontribusi sebesarRp. 4.353.022.000,atau $21,29 \%$, maka ADD sangat menunjang peningkatan penyelenggaraan pemerintahan, pembangunan dan kemasyarakatan.

Kedua, peningkatan kemampuan lembaga kemasyarakatan di desa dalam perencanaan, pelaksanaan dan pengendalian pembangunan. Pencapaian tujuan ini belum berjalan secara optimal, karena lembaga kemasyarakatan hanya dilibatkan dalam penyusunan rencana kegiatan sedangkan dalam pelaksanaan dan pengendalian tidak dilibatkan. Ketiga peningkatan partisipasi swadaya gotongroyong masyarakat. Pencapaian tujuan inimasih sangat rendah. Berdasarkan data yang penulis peroleh dilapangan mengenai proses kegiatan pembangunan yang dibiayai dari ADD terlihat bahwa hanya Rp. 207.227.450,- dari Total anggaran Alokasi Dana Desa di wilayah Kecamatan Ringinrejo yang sebesar Rp. 4.353.022.000,- atau hanya sebesar4,7\% saja adanya partisipasi dan swadaya masyarakat. Belum optimalnya pencapaian tujuan ini dikarenakan karena kondisi perekonomian masyarakat yang kurang mendukung. Namun demikian masyarakat masih berpartisipasi, swadaya dan gotong-royong dalam bentuk tenaga dan material.

\section{Faktor-Faktor Pendukung Pelaksanaan ADD}

Faktor-faktor yang mendukung pelaksanaan Alokasi Dana Desa (ADD) di Kecamatan Ringinrejo Kabupaten Kediri adalah:

a) Adanya sosialisasi yang dilakukan tim kabupaten maupun kecamatan.

b) Adanya kejelasan informasi/komunikasi dari pembuat kebijakan ke pelaksana.

c) Adanya konsistensi dalam pencapaian pesan.

d) Adanya kemampuan para pelaksana untuk mendorong masyarakat. e) Adanya kemampuan para pelaksana untuk melakukan identifikasi dan menyelesaikan masalah.

f) Adanya kelengkapan sarana dan prasarana.

g) Adanya persepsi yang mendukung.

h) Adanya peran BPD dalam pengawasan.

\section{Faktor-Faktor Penghambat Pelaksanaan ADD}

Faktor-faktor yang menghambat pelaksanaan Alokasi Dana Desa (ADD) di kecamatan Ringinrejo kabupaten Kediri adalah:

a) Rendahnya tingkat pendidikan perangkat desa.

b) Kurang respon para pelaku ADD, rendahnya kinerja tim pelaksana $\mathrm{ADD}$, belum berperannya lembaga kemasyarakatan desa, kurang tepatnya sasaran.

c) Aspek regulasi dan kelembagaan (belum lengkapnya peraturan dan petunjuk teknis pelaksanaan ADD).

d) Belum efektifnya pengawasan.

\section{E. KESIMPULAN DAN REKOMENDASI}

Setelah dilakukan penelitian secara mendalam ternyata permasalahan implementasi kebijakan Alokasi Dana Desa (ADD) di desa-desa di kecamtan Ringinrejo kabupaten Kediri terletak pada proses pencairan oleh desa ataupun pendistribusian dana ADD dari kepala desa ke bendahara. Selain itu, masalah juga terdapat pada penyusunan Daftar Usulan Rencana kegiatan (DURK) dan adanya faktor-faktor penghambat yaitu rendahnya tingkat pendidikan aparatur desa, lemahnya kinerja tim pelaksana Alokasi Dana Desa, belum detailnya peraturan dan petunjuk teknis pelaksanaan Alokasi Dana Desa dan tidak adanya pengawasan yang ketat.

\section{F. REFERENSI}

Moleong, Lexy .J. 2006. Metodologi Penelitian Kualitatif. Bandung. PT. Remaja Rosdakarya.

Patilima, Hamid. 2010. Metode Penelitian Kualitatif. Malang: UMM Press.

Rachim, Abd. 2015. Barometer Keuangan Negera. Yogyakarta: CV Andi Offset 
Sadu, Wasistiono \&Tahir, M. Irwan. 2006. Prospek Pengembangan Desa.

Fokusmedia: Bandung.

Subarsono, A.G.2005. Analisis Kebijakan Publik. Yogyakarta: Pustaka Pelajar.

Sugiyono.2015.Memahami Penelitian Kualitatif. Bandung: CV. Alfabeta.

Uhar, S. 2012. Metode Penelitian: Kuantitatif, Kualitatif, dan Tindakan. Bandung: PT. Refika Aditama.

Wibawa, Samodra, dkk. 1994. Evaluasi Keijakan Publik. Jakarta: PT. Raja Grafindo Sumber Internet:

Kamus Bahasa Indonesia Daring: www.kbbi.web.id

Situs Resmi Kabupaten Kediri: www. kedirikab.go.id

Sumber Naskah:

Petunjuk Tenknis Alokasi Dana Desa Nomor 412.6/1843/418.63/2015 Perihal Petunjuk Teknis Alokasi Dana Desa Kabupaten Kediri Tahun 2015.. Persada. 